\title{
Bimbingan Literasi Media dan Pengarus Utamaan Moderasi Beragama di PPM-PIN IAIN Surakarta
}

\author{
Rahmaditta Kurniawati \\ UIN Sunan Kalijaga, Yogyakarta, Indonesia \\ rahmadittakw@gmail.com \\ Maemonah \\ UIN Sunan Kalijaga, Yogyakarta, Indonesia \\ maimunah@uin-suka.ac.id
}

\begin{abstract}
In this Era pf massive digital development, people can acsess information very easily. This can have both possitive and negative effects. The lack of media literacy skills makes people become victims of hoax news and even become victims of provocations from ekstremist community. Throught media literacy skills, internt users can recive the benifits of the media, namely as a means of communication and obtining information. This articleis aim to investigate how PPM-PIN Institut Agama Islam Negeri IAIN Surajarta in vocalize and guide milenial generation (Senior high school students and university students) in developing media literacy capability in effort of religion moderation. In the process, the research use descriptive qualitative. The collecting data of the research apply observation and interview and documentation. The subject in this study were 5 members of the PPM-PIN IAIN Surakarta. Based on the finding of this research, the researcher finds that though literacymedia guidance that is conducted by PPM-PIN IAIN Sureakarta produce education atmosphere whose high religion moderation. As a result, the research is expected can create tolerance in piece lifebetween religious comunity. The output of the religion moderation is creating tolerance life, piece between religious comunity.
\end{abstract}

Keywords: Mecia Literacy; Religion Moderation; PPM-PIN 


\begin{abstract}
Abstrak
Di era perkembangan dingital yang masif ini, masyarakat dapat mengakses informasi dengan begitu mudah. Hal ini dapat memberikan efek positif maupun negatif. Minimnya kemampuan literasi media membuat masyarakat menjadi korban berita hoax dan bahkan menjadi korban profokasi kelompok ekstrimis. Melalui kemampuan literasi media, pengguna internet dapat menerima manfaat dari media yaitu sebagai sarana komunikasi dan mendapatkan informasi. Artikel ini bertujuan untuk mengetahui bagaimana PPM-PIN IAIN Surakarta dalam menyuarakan dan membimbing masyarakat, khususnya generasi milenial (siswa Madrasah dan Mahasiswa) dalam mengembangkan kemampuan literasi media sebagai upaya moderasi beragama. Dalam prosesnya peneliti menggunakan kualitatif deskriptif. Pengambilan data dalam penelitian ini menggunakan observasi dan wawancara.Subjek dalam penelitian ini adalah 5 anggota PPM-PIN IAIN Surakarta. Berdasarkan hasil yang didapat dari proses penelitian ini, bahwa melalui bimbingan literasi media yang dilakukan oleh PPM-PIN IAIN Surakarta dapat menumbuhkan kesadaran toleransi dan keharmonisan dalam kehidupan bermasyarakat. Selain itu PPM-PIN mampu mencetak duta lisan yang bertugas untuk mengkapanyekan Islam yang ramah dan santun baik melalui media sosial maupun secara langsung.
\end{abstract}

Kata kunci: Literasi Media; Moderasi Beragama; PPM-PIN

\title{
A. Pendahuluan
}

Pesatnya arus teknologi telah mendorong derasnya informasi yang beredar (Tutiasri \& Kusuma, 2019). Penetrasi internet berkembang pesat di dunia tak terkecuali di Indonesia. Berdasarkan hasil survey yang dilakukan Asosiasi Penyelenggara Jasa Internet Indoensia (APJII, jumlah pengguna internet pada tahun 2019 per bulan juni mencapai 171,26 juta jiwa. Angka tersebut menjadikan Indonesia berada di posisi pengguna internet tertinggi keempat di dunia. (Syam \& Nurrahmi, 2020).

Media secara universal telah mengalami perubahan signifikan dengan teknologi komunikasi digital, telah bertransformasi ke media sosial virutual dan simultan dan hal ini membawa pendidikan literasi media ke tingkat yang lebih tinggi dibandingkan dengan literasi media tradisional (Kaplan, 2019).

Media sosial memiliki pengaruh positif, dimana pengguna internet seolah-olah dekat satu sama lain dengan mengetahui informasi pengguna lain ketika berbagi informasi di media sosial. Media sosial muncul pada tahun 2002, diawali dengan adanya apliakasi Frindster, kemudian berlanjut media sosial lainnya Linendin, My Space, Flick, Facebook dan twitter. Hal ini membuat dapat saling berbagi informasi dan bahkan 
membuat pengguna media sosial menjadi terkenal (Tutiasri \& Kusuma, 2019). Media sosial adalah alat penting dalam membangun komunikasi dan mengkonsolidasikan hubungan pertemanan, kerabat dan rekan kerja (Musa et al., 2017).

Namun demikian, pengguna media sosial sebagai aktivitas utama dalam menggunakan internet menyebabkan seseorang tersebut memiliki ketergantungan media sosial. Ketergantungan ini disebabkan karna beberapa faktor diantaranya adalah sistem sosial dan sistem kepribadian (Musa et al., 2017). Disamping itu, dampak negatif lain dari media sosial adalah masifnya keberadaan berita hoax atau berita bohong. Dalam kondisi pandemi global Covid-19 tidak menutup kemungkinan adanya penyebaran berita hoax. Apalagi jika kita cermati, bahwa berita hoax seringkali mengarah pada isu ekonomi, politik, suku, agama yang menimbulkan masalah rumit (Kosasih, E. (2019). Filter Bubble, akan membuat pengguna internet terpapar informasi sesuai dengan apa yang diyakininya, jika ada yang tidak sesuai maka jumlahnya sangat minim (Aisyiyah, Putri, 2021).

Menurut Tandoc, Lim dan Liang (2018) mendefinisikan berita palsu dengan adanya penyebaran informasi dengan niat menipu. Sementara Molina, Sundar, Le dan Lee (2019) berpendapat bahwa berita palsu tidak hanya dilatarbelakangi oleh motif penyebaran berita palsu, tapi juga dijadikan senjata politik unutuk memberikan klaim pada satu tujuan tertentu (Syam \& Nurrahmi, 2020).

Fenomena lain, bahwa kelompok ektrimis menggunakan internet sebagai basis kekuatan untuk merekrut anggota secara internasional. Kelompok ini telah menggunakan Internet sebagai sarana komunikasi, panggilan data perekrutan, mobilisasi masa, memberikan intruksi anggota, memberikan contoh tatacara online perakitan bom, penggalangan dana dan menjadi sarana untuk menyerang kelompok saingan (O'Hara \& Stevans, 2009). Ektrimisme adalah tantangan tersendiri umat beragama. Hal ini disebabkan karna ekstrimisme mampu merusak ajaran agama secara internal dan eksternal serta citra iman yang buruk. Ekstrimisme adalah tantangan di abad ke-21 (Mansyur \& Husni, 2020).

Menyikapi fenomena tersebut, maka kita perlu memiliki benteng untuk melindingi diri dari sisi negative media yaitu dengan meningkatkan kemampuan literasi media. Menurut Potter Literasi media bisa dimaksud sebagai kemampuan interprestasi makna dari pesan yang membutuhkan struktur pengetahuan berupa keahlian sebagai alat, serta kekayaan informasi sebagai bahannya. Potter juga menjelaskan bahwa informasi yang dimaksud adalah informasi multidimensi. Tidak hanya berupa fakta yang bisa diakses melalui media cetak saja tetapi juga meliputi media informasi 
elektronik, informasi emosional, informasi estetis, informasi estetis dan informasi moral. (Sabrina, 2019).

Kemampuan literasi media menjadi penting karena harapannya mampu memebentuk perilaku moderasi beragama. Moderasi beragama berasal dari kata alWasath juga ditemukan dalam hadis yang sangat popular yang berarti terbaik, paling sempurna. Dalam hadis tersebut disebutkan bahwa sebaik-baiknya persoalan adalah yang berada di tengah-tengah (Sutrisno, 2019). Moderasi beragama berarti tidak ekstrim dalam menerapkan ajaran agama. Berbagai perilaku intoleran seperti ekstremisme, radikalisme, dan ujaran kebencian sering kali terjadi di dalam relasi sosial masyarakat. Hal ini berdampak pada retaknya hubungan antara umat beragama, sehingga berpijak dari sinilah moderasi beragama dirasa sangat penting digaungkan disetiap lini kehidupan (Novia \& Wasehudin, 2020).

Moderasi beragama dan wacana pendidikan menjadi diskusi menarik. Masyarakat Indonesia telah memiliki kesadaran urgensi moderasi beragama, terutama setelah jumlah peristwa kekerasan yang mengatasnamakan agama, baik di wilayah nasional maupun global (Mahrus et al., 2020). Namun disisi lain terdapat, lembaga pendidikan menjadi pergolakan ideologi transnasional yang menentang ideologi bangsa Indonesia. Mereka menyusup dalam benak pikiran peserta didik di dalam ruang kelas maupun di luar kelas. Sehingga hal ini berdampak pada minimnya pemahaman kebangsaan keagamaan yang formalis (Sutrisno, 2020)

Para tokoh berusaha keras untuk memberikan ruang pendidikan yang moderat. Hal ini dapat dilihat dari upaya dalam merekontruksi ulang kurikulum pendidikan yang moderat menuju pada Islam yang memegang teguh prinsip moderasi beragama. Melalui pendidikan berbasis moderat ini, memberikan angin segar bagi para pelajar, dimana basis pendidikan sangat menjujung tinggi dasar-dasar moderasi beragama (Bagi et al., 2021). Pada saat ini moderasi beragama menjadi program prioritas bagian dari revolusi mental dan pembangunan budaya dalam Rencana Pembangunan Jangka Menengah Nasional (RPJM) 2020-2024. Hal ini menguatkan bahwa moderasi beragama menjadi landasan dan sikap dan perilaku keagamaan (Fuadi et al., 2021).

Kajian tentang moderasi beragama di Indonesia telah dilakukan oleh sejumlah peneliti. Wildan Hefni (2020) misalnya, penelitian ini memfokuskan tentang pengarusutamaan moderasi beragama di ranah digital sebagai narasi keagamaan yang ramah dan toleran. Bahwa ada upaya Perguruan Tinggi Keagamaan Islam Negeri (PTKIN) dalam menggaungkan moderasi beragama di era digital ini. Selanjutnya penelitian dari Engkos Kokasih (2019) penelirtian ini mengkaji tentang wacana yang 
membentuk sikap berbeda dari media sosial yaitu dengan berfikir kritis dan moderat terhadap isu-isu yang tersebar di media sosial khususnya dalam hal moderasi beragama. Edi Sutrisni (2019) juga membicarakan moderasi beragama khususnya konsep aktualisasi moderasi beragama pada masyarakat multikultural. Dalam mewujudkan masyarakat yang memiliki karakter moderasi beragama, maka memerlukan beberapa langkah taktis antara lain: mewujudkan ruang lembaga pendidikan sebagai basis laboratorium moderasi beragama. Usaha mewujudkan moderasi beragama pada masyarakat multikultural juga harus diberlakukan pada ranah pendidikan. Selanjutnya penelitian dari Arifiansyah et. al (2020) berbicara tentang pentingnya moderasi beragama dalam melawan radikalisme. Menghadapi keragamaan Indonesia, dalam merawat keutuhan dan kebhinekaan, maka perlu adanya pembinaan moderasi beragama yang dapat dijalankan dikalangan masyarakat. Moderasi beragama merupakan misi kenabian yang mendorong pengikutnya untuk menjadikannya sebagai gaya hidup.

Artikel ini memfokuskan untuk melihat bagaimana penerapan bimbingan literasi media sebagai upaya moderasi beragama di Pusat Pengkajian Masyarakat dan Pendidikan Islam Nusantara (PPM-PIN) IAIN Surakarta. Objek bimbingan diberikan ditujukan pada masyarakat umum dan pendidikan Islam di Indonesia, serta Perguruan Tinggi Islam Indonesia (PTKIN). .Peneliti memilih lembaga pengkajian ini dikarenakan pergerakannya selama 2017 hingga kini cukup masif menggaungkan moderasi beragama, salah satunya melalui media online Islam Santun. Web tersebut difungsikan untuk mewartakan nilai-nilai Islam moderat dan toleran. Sisamping itu, PPM-PIN secara masif melakukan pendampingan peningkatan kapasistas intelektual siswa madrasah dan mahasiswa Perguruan Tinggi Negeri Islam (PTKIN) mengenai keislaman khususnya niali-nilai moderasi beragama. Seperti, pelatihan Literasi Islam Santun (LISAN) yang diikuti para mahasiswa IAIN Surakarta.

Selajutnya berbagai aktifitas peningkatan kapasitas diri siswa madrasah dan mahasiswa juga dilakukan oleh PPM-PIN. Kegiatan tersebut dapat berupa diskusi terbuka dan pelatihan intensif. Berdasarkan data yang diambil dilapangan, kegiatan PPM-PIN diantaranya adalah pelatihan Literasi Islam Santun (lisan) yang diikuti oleh para mahasiswa IAIN Surakarta. Pelatihan ini bertujuan untuk dapat meningkatkan kapasitas diri peserta dalam literasi media. Output dari kegiatan ini adalah mampu mencetak duta literasi santun, dimana tugas duta literasi santun adalah menjadi bagian dari PPM-PIN dalam mengkampanyekan Islam yang ramah, santun dan moderasi beragama.

Perbedaan penelitian terdahulu dengan penelitian dalam artikel ini terletak pada titik fokus, dimana penelitian terdahulu lebih bersifat global atau luas, sedangkan penelitian ini lebih mengerucut pada satu lembaga tertentu. Dengan demikian artikel ini 
berusaha menjawab pertanyaan mengenai bagaimana bimbingan literasi media dan pengarusutamaan moderasi beragama di PPM-PIN IAIN Surakarta.

Penelitian ini menggunakan metode kuanlitatif dengan jenis deskriptif, dimana peneliti melakukan diskripsi kejadian sekarang ini. Subjek dalam penelitian ini merupakan dosen dan anggota kepengurusan PPM-PIN UIN Raden Mas Said. Peneliti menggambil subjek sebanyak 5 orang untuk diambil datanya sebagai sumber utama. Pemilihan subjek menggunakan teknik purposive sampling, dimana subjek yang dipilih berdasarkan pertimbangan tertentu. Kelima subjek tersebut memahami dan terlibat dalam kegiatan PPM-PIN, sesuai dengan tugas dan jabatan masing-masing. Berikut subjek penelitian artikel ini:

Tabel 1. Subjek Penelitian

\begin{tabular}{l|l}
\hline \multicolumn{1}{c|}{ Nama } & \multicolumn{1}{|c}{ Struktural PPM-PIN } \\
\hline AK (Subjek 1) & $\begin{array}{l}\text { Anggota PPM-PIN dan Duta } \\
\text { Lisan }\end{array}$ \\
\hline AW(Subjek 2) & Pimpinan redaksi Islam santun \\
\hline NR(Subjek 3) & Wakil Direktur PPM-PIN \\
\hline AH (Subjek 4) & Direktur PPM-PIN \\
\hline ZA(Subjek 5) & $\begin{array}{l}\text { Peneliti dan Mantan Direktur } \\
\text { PPM-PIN }\end{array}$ \\
\hline
\end{tabular}

Teknik pengumpulan data menggunakan observasi, wawancara dan dokumentasi. Peneliti mengobservasi secara langsung kantor PPM-PIN agar memperloeh data yang valid, yang kemudian peneliti catat kondisi lapangan yang terjadi. Selanjutnya peneliti menggali data menggunakan jenis wawancara terstruktur. Maka dalam hal ini subjek penelitian diminta menjawab pertanyaan yang sudah disajikan peneliti dalam panduan wawancara. Untuk keabsahan data, peneliti menggunakan triangulasi sumber, dimana peneliti mebandingkan dan mengecek ulang informasi yag diperoleh melalui alat yang berbeda.

\section{B. Pembahasan}

\section{Literasi Media}

Seiring dengan perkembangan zaman, teknologi dan internet telah merebak di seluruh wilayah tanpa terkendalikan. Perkembangan teknologi telah memberikan sisi positif dan negative, yang mana keduanya dapat begitu terasa oleh masyarakat pengguna media sosial. Perkembangan teknologi telah mempermudah masyarakat untuk 
mengakses informasi yang datang dari belahan dunia. Seperti halnya teknologi komunikasi media sosial antara lain facebook, whatsapp, twitter dll (Ulya, 2018).

Media sosial yang cenderung mudah diakses dalam berkomunikasi dan mendapatkan informasi berimplikasi pada timbulnya efek kecanduan sehingga anak muda sebagai pengguna media sosial terbesar akan mengakses internet tanpa ada batasan. Maka, pemahaman dan pendidikan mengenain literasi media harus benar-benar diperhatikan (Briandana \& Ninditya, 2019). Menurut Giles (2010) penggunaan internet yang berlebihan memiliki arah tujuan kepentingan hubungan sosial daripada mendapatkan informasi. Hal ini adalah daya tarik pengguna internet dan memberikan pengaruh yang sangat tinggi dalam kehidupan bermasyarakat (Briandana \& Ninditya, 2019).

Disamping itu, perkembangan media dapat memberikan peningkatan pengaruh pada meningkatnya sikap intoleransi generasi milenial atau generasi Z. Penelitian dari PPIM UIN Jakarta. Siswa dan mahasiswa yang tidak memiliki akses internet berpeluang besar pada tingginya sikap inteleran sebesar $84,94 \%$. Sedangkan sisanya yaitu $15,06 \%$ siswa atau mahasiswa tidak memiliki akses internet. Data yang ditemukan, pada umumnya siswa dan mahasiswa belajar agama melalui internet, baik itu medsosos, blog, websitite (Ibrahim, 2020)

Kata "literasi" yang berarti kemampuan dalam membaca dan menulis, kini mengalami perkembangan makna di era digital ini. Seiiring dengan perkembangan zaman, literasi bukan saja mengacu pada literasi membaca, tetapi juga mengarah pada literasi visual, serta literasi computer. Kemampuan literasi dewasa ini, erat kaitannya dengan pemrosesan informasi berupa memilah, mencocokkan makna, serta mengkrontruksi makna dari media (Sabrina, 2019)

Cervi, Paredes \& Tornero mengemukakan bahwa literasi media pada dasarnya merupakan perkembangan lebih lanjut dan komeprehensif dari literasi klasik (misal membaca, menulis) Literasi audio visual , digital literasi, dan yang lebih komprehensif, yakni literasi media baru. Mereka juga mengungkapkan bahwa literasi media baru bersifat multiliterasi, yang meliputi di dalamnya merupakan kombinasi antara information literacy skill, conventional literacy skill, and social skill (Rianto, 2019).

Menurut Potter (Sabrina, 2019) Literasi media bisa diartikan sebagai kemampuan interprestasi makna dari pesan yang membutuhkan struktur pengetahuan berupa keahlian sebagai alat, serta kekayaan informasi sebagai bahannya, disamping itu Potter juga menjelaskan bahwa informasi yang dimaksud adalah informasi yang bersifat multidimensi.Tidak hanya berupa fakta yang bisa diakses melalui media cetak saja 
tetapi juga meliputi media informasi elektronik, informasi emosional, informasi estetis, informasi estetis dan informasi moral.

Kemampuan literasi media ini adalah kompetensi yang harus dimmiliki diera digital ini. Berdasarkan piagam Eropa, mencantumkan tujuh kompetensi dasar yang harus dimiliki pengguna media sosial, diantaranya adalah menggunakan media secara efektif, mengakses dan membuat pilihan berdasarkan informasi tentang konten media, memahami proses pembuatan konten media, menganalisis informasi media, menggunakan media untuk berkomunikasi, menghindari dan layanan media yang berbahaya dan menggunakan nfasilitas media untuk kepentingan demokrasi dan tujuan sipil (Eristi \& Erdem, 2017).

Disamping itu, menurut Chen et al, (2011) kuadran dan indikator literasi media diantaranya adalah, 1) memiliki kemampuan untuk mengakses konten media . Dalam hal ini pengguna media sosial tidak hanya mengkonsumsi informasi, namun juga memahami makna tekstual dan konten informasi tersebut. 2) Dapat mengkonsumsi media sosial dengan berfikir kritis, dalam konteks sosial, politik, ekonomi dan budaya. Mengkonsumsi kritis indikatornya meliputi, memiliki ketrampilan analisis, ememiliki ketrampilan sintesis (memandingkan informasi dari berbagai sumber terpercaya), dan evaluasi (mengkritik informasi media). 3) Prosuming, yaitu kemampuan untuk mengoperasikan dan menyebarkan konten media, 4) Critical Prosuming, yaitu kemampuan untuk menginteprestasikan kontes dari konten medai yang tersebar. Beriringan dengan kemampuan berpartisipasi secara aktif dan kritis (Syam \& Nurrahmi, 2020).

Maka, melalui berbagai pendapat tersebut dapat disimpulkan bahwa literasi media adalah kemampuan seseorang untuk menelaah, menganalisis informasi yang di dapatkan, sehingga melalui kemampuan ini manusia bisa menerima manfaat dari media tersebut yaitu sebagai sarana komunikasi dan mendapatkan informasi. Penggunaan literasi media sosial memiliki peran yang penting dalam menjawab tantangan baru di tengah kemajuan teknologi, seperti halnya fake news, hoax, cyberbullying dan lain-lain. Melalui kemampuan literasi media, masyarakat diharakan mampu memilah, memetakan, mengakses, mengelola dan mengevaluasi sebuah informsi, sehingga mampu mengambil keputusan yang tepat, ceat dan cerdas (Kosasih, 2019).

\section{Mengenal Moderasi Beragama}

SMA Moderat dalam bahasa arab dikenal dengan al-wasathiyah. Kata ini terdapat dalam firman Allah, Al-Qur'an surat Al-Baqarah ayat 143. Kata al-Wasath juga ditemukan dalam hadis yang sangat popular yang berarti terbaik, paling sempurna. Dalam hadis tersebut disebutkan bahwa sebaik-baiknya persoalan adalah yang berada di 
tengah-tengah. Hal ini bermakna melihat dan menyelesaikan satu persoalan, Posisi Islam yang moderat mencoba melakukan pendekatan kompromi dan berada ditengahtengah, pun demikian dalam merespon sebuah perbedaan, baik dalam agama maupun mazhab. Islam moderat selalu menitikberatkan pada sikap toleransi, saling menghargai, dengan tetap menyakini kebenaran masing-masing agama dan mazhab. Maka, dengan demikian, hal ini bermuara pada keberterimaan seseorang dalam putusan-putusan yang sudah ditentukan, dengan kepala dingin, tanpa harus menggunakan unsur kekerasan (Sutrisno, 2019).

Hashim Kamali, mengungkapkan bahwa moderate, tidak dapat terlepas dari kedua kata kunci lainnya, yaitu berimbang (balance), dan adil (justice) Yang perlu diperhatikan bahwa, menjadi moderat bukan berarti kita turut kompromi dengan prinsip-prinsip pokok (ushuliyah) ajaran agama yang diyaini demi bersikap toleran terhadap umat agama lain; moderat berarti “.....confidence, right balancing, and justice”. Moderasi beragama tidak akan efektif jika tanpa adanya keseimbangan dan keadilan. Maka dari itu, moderat dapat dimaksud dengan tidak bersikap ekstrem di masing-masing sisi pandangnya. Keduanya harus mendekat dan mencari titik temu, (Sutrisno, 2019).

Para Cendikiawan Muslim telah membahas masalah wasatiyah yang memiliki peranan penting dalam membangun kehidupan yang adil da makmur. Term ini telah dikenal sejak tahun 1970-an, yang dipopulerkan oleh Muhammad Abu Zahrah dan Muhammad Al-Madani Kata wasatiyah dari akar kata wasat yang berasal dari Al-qur'an dengan padanan kata tawassut (tengah-tengah), tawazun (berimbang) dan I'tidal (adil) (Husain, 2020).

Moderasi beragama tidak lepas dari terma toleransi, atau toleran. Hal ini berarti bahwa moderasi beragama adalah proses dan disisi lain toleransi adalah hasil (outcome) dari sikap moderasi beragama. Istilah toleransi dapat diartikean sebagai bentuk kelapangan dada, dalam pengertian suka kepada siapapun, memberikan ruang orang lain untuk berpendapat atau bertegung pendirian, tidak menganggu kebebasan berfikir dam keyakinan lain. Toleransi dalam konteks ini dapat dimaknai sebagai satu sikap keterbukaan mendengar perbedaan pendapat.mArah gerak toleransi, diberlakukan secara bersamaan yaitu dalam mengemukakan pandangan dan menerima pandangan dalam batas tertentu namun tidak merusak agama dan keyakinan masing-masing. Dengan membuminya sikap toleran dan saling menghargai satu sama lain antar umat beragama, maka hal ini akan membentuk interaksi sosial dan saling memahami di kalangan umat beragama sehingga menghasikanterciptanya tata kehidupan yang aman, tentram dan rukun (Ibrahim, 2020). 
Berdasarkan temuan dari lembaga Kerukunan Umat Beragama (KUB) yang diterbitkan oleh Puslitbang Bimas Agama dan Layanan Keagamaan 2019, indikaor yang paling berperan dalam membentuk kerukunan umat antar beragama adalah toleransi. Toleransi menghasilkan kehidupan umat antar beragama dapat berlangsung secara harmonis, toleran, damai saling menghormati perbedaaan agama dan kebebasan menjalankan ibadat masing-masing. Konsep Bhineka Tunggal Ika di Indonesia dapat bertahan jika kita memegang teguh prinsip toleransi. Dimana toleransi yang dilakukan dengan ketulusan hati(Ibrahim, 2020)

Moderasi merupakan ajaran islam yang sangat fundamental. Islam yang moderat adalah paham keagamaan yang sangat relevan dengan kondisi keberagaman dalam segala aspek kehidupan seperti agama, ras, adat istiadat, suku dan bangsa. Tidak dapat dipungkiri bahwa keberagaman ini adalah bagian dari fakta sejarah peradaban Islam. Hal ini berasal dari adanya dialektikaantara teks dan realitas, sertacara berfikir terhadap posisi akal dan wahyu dalam menyelesaikan masalah(Sutrisno, 2019).

Moderasi memfokuskan pada suatu sikap, yang berarti dalam setiap kasus memiliki gaya moderasi yang berbeda-beda. Di Negara mayoritas muslim ini, sikap moderasi ini dapat mencakup soal; pengakuan atas eksistensi kelompok lain, toleransi terhadap perbedaan, menghormati perbedaan pendapat, tidak memaksakan kehendak orang lain dengan cara kekerasan. Landasan konsep dalam pemikiran ini terdapat dalam ayat-ayat al-Qur'an, antara lain menghargai kemajemukan dan kemauan berinteraksi (QS. An-Nahl: 125) dan mengedepankan, prinsip kemudahan sesuai kemampuan (QS. Al-Baqarah: 185, al-Baqarah: 286 dan QS. Al-Tagghabun: 16) (Sutrisno, 2019).

Para santri di Indonesia telah memberikan sumbangsih yang besar untuk perkembangan sikap moderat. Tertuang dalam ajaran Islam yaitu tentang akidah (keyakinan), ibadah (pelaksanaan hukum dan ritual keagamaan), dakwah (syiar agama), dan akhlak (etika). Disamping itu, Kyai di pondok pesantren mengajarkan kepada santrinya bahwa perilaku Al-Ghuluw (melampaui batas) dalam beragama adalah perilaku yang tidak baik, bisanya kyai menegur santrinya yang melakukan tindakan ini. Fanatisme yang berlebihan terhadap suatu pandangan tentu akan mempersulit pelaksanaan agama Islam. Sikap santri moderat dapat diimplementasikan di masyarakat dengan beberapa cara strategis pemahaman dengan pengalaman teks-teks keagamaan yang ditandai degan ciri khas tersendiri, contoh pemahaman terhadap realitas (fiqh alwaqi'), pemahaman pada fiqh prioritas (fiqh awwaliyyat), pemahaman tentang konsep suatullah dalam pencipptaan makhluk, pemahaman terhadap Al'qur'an dan Hadis secara komprehensif, memberikan kemudaan kepada seseorang dalam menjalankan agama yang dianutnya memberikan ruang untuk berdialog, toleransi terhadap perbedaan, serta sikap terbuka denan dunia luar (Awwaliyah, 2019). 
Moderasi beragama berpegang pada prinsip nilai-nilai egaliter (musawah). Hal ini berarti bahwakonsep moderasi beragama menyikapi dan merespon sebuah fenomena anti diskriminatif terhadap yang lain. Perbedaan segala aspek kehidupan, baik keyakinan, tradisi, agama, bahasa, ras, suku, bangsa tidak menjadikan seseorang menjadi "memilki hak khusus" sehingga dapat merusak persaudaraan. Dengan menjalani kehidupan bermasyarakat berlandaskan moderasi beragama, dapat menjadi solusi alternatif atau jalan tengah untuk mewujudkan kehidupan yang damai dan sejahtera ditengah keberagaman (Hefni, 2020). Sedangkan indikator moderasi beragama menurut kemenag, yang dituangkan dalam buku panduannya meliputi:

\section{a. Komitmen kebangsaan,}

Poin ini menjadi sebuah indikator yang sangat penting. Penerimaan prinsip-prinsip berbangsa termaktub dalam Undang-Undang Dasar 1945 dan regulasi dibawahnya. Lukman Hakim Saifuddin, selaku mantan Menteri Agama mengungkapkan bahwa, melaksanakan ajaran agama sama menjalankan kewajiban sebagai warga negara yang baik (Kementrian Agama RI, 2020).

\section{b. Toleransi}

Toleransi adalah sikap memberikan ruang untuk menghargai oranglain dalam mengekspresikan keyakinan dan menyampaikan pendapat.meski tidak sependapat degan hal tersebut. Maka sikap toleransi dapat ditandai dengan sikap terbuka, lapang dada, suka rela dan lembut dalam menerima perbedaan. Toleransi senantiasa disertai dengan sikap menghormati dalam menerima perbedaan dan memaknai perbedaan menjadi sutu hal yang positif (Kementrian Agama RI, 2020).

\section{c. Anti kekerasan}

Kekerasan atau radikalisme dapat dipahami sebagai sebuah yang dilakukan oleh sekelompok tertentu, untuk merubah sistem sosial dan politik denga cara kekerasan/ekstrem atas dasar nama agama. Radikalisme dilakukan tidak hanya oleh satu agama tertentu, melainkan bisa melekat pada seluruh agama. Radikalisme ini dapat dipicu oleh rasa ketidakadilan dan keterancaman yang dialami oleh sekelompok orang. Persepsi ini akan terus mencuat jika ideologi yang digunakan memunculkan aspek kebencian terhadap kelompok tertentu yang diklaim telah berbuat tidak adil. Keadilan yang dimaksud meliputi berbagai aspek, seperti ketidakadilan sosial, ekonomi dan politik. Klaim sepihak tersebut, dapat memicu dukungan pada radikalisme, bahkan terorisme, meski hal ini belum tentu seorang individu bersedia melakukan tindakan radikal dan terror (Kementrian Agama RI, 2020). 


\section{d. Akomodatif Budaya Lokal}

Individu moderat memiliki kecenderungan yang lebih ramah dalam menerima tradisi dan budaya lokal dalam perlaku keagamaan, asal tidak bertentangan dengan ajaran pokok agama. Tradisi keagamaan yang tidak kaku dapat ditandai dengan ketersediaan individu atau kelomppok dalam menerima praktik dan perilaku yang tidak hanya terpaku pada kebenaran normatif, namun juga dapat menerima praktik beragama yang didasarkan pada keutamaan tertentu. Hal yang perlu dicatat adalah, tidak boleh melanggar prinsip ajaran agama (Kementrian Agama RI, 2020).

Yusuf Qardhawi juga mengemukakakn indikator moderasi beragama, daiantaranya 1) Memiliki intrepestasi Islam yang holistik, 2) Dapat berkompromi antara syari'ah dan trend modern, 3) Tidak menggunaan jalan kekerasan, 4) Menerima pluralitas agama, budaya dan politik, 5) Mengakui hak-hak kaum minoritas (Abdullah \& Nento, 2021).

Selanjutnya, Menurut Quraish Shihab, indikator moderasi beragama pertama, memiliki fleksibilitas dan pembaharuan (tajdid). Salah satu indikator dari moderasi beragama adalah mampu menerima pembaharuan dan dapat menyesuaikan keadaan lingkungan. Inilah yang disebut dengan Islam rahmatan lil/alamin. Kedua, kemudahan (taysr) karna Islam diturunkan untuk memberikan kemudahan bagi umatnya. Ketiga, toleransi (tasamuh) toleransi yang berarti menghargai keragaman perbedaan, menunda penilaain dan menghargai ekspresi pengalaman keagamaan oranglain (Mahrus et al., 2020).

\section{Literasi Media Sosial sebagai Upaya Moderasi Beragama di PPM-PIN}

Pusat Pengkajian Masyarakat dan Pendidikan Islam Nusantara atau disingkat dengan PPM-PIN, merupakan pusat pegkajian yang berfokus pada pendidikan moderasi beragama ditataran masyarakat maupun dunia pendidiakan yang meliputi RA, Madrasah dan Perguruan Tinggi". PPM-PIN telah bertransformasi dari yang dahulu dikenal dengan nama Pusat Kajian Pengembangan Pesantren Nusantara (PKPPN). Pengubahan nama ini dikarenakan ingin memperlebar cakupan scoop yang lebih luas yaitu masyarakat dan pendidikan nusantara.

Terbentuknya pusat pengkajian ini berawal dari semangat para dosen baru UIN Raden Mas Said dalam rangka mengembangkan mimbar akademik dari berbagai lintas keilmuan dosen, dalam menggaungkan nilai-nilai islam yang rahmatan lil'alamin. Hal ini menjadi penting karena, mengingat lokasi UIN Raden Mas Said terletak di wilayah Solo-raya, yang mana wilayah ini menjadi zona merah BNPT. Sedangkan peran UIN Raden Mas Said sendiri pada masa itu belum cukup masif dalam mengcounter 
mengenai isu-isu radikalisme. Berpijak pada permasalahan inilah yang memberikan dorongan tersendiri bagi PPM-PIN untuk menjadi agen penggerak moderasi beragama dan Islam yang rahmatan lil-alamin.

"Pada pertengahan okteber 2015, kita ada jejaring Asosiasi Pesantren NU mau mengadakan acara semacam pertemuan regional se Jawa Tengah yang bertempat di IAIN Surakarta, akhirnya dari situ kita ngobrol-ngobrol dan ada ide mendirikan pusat studi.Terus di launcing lah pusat studinya" (Wawancara. ZA.subjek 5.20 April2021)

Setelah selesai mengurus administrasi mendirikan pusat studi di rektorat, maka turunlah SK Rektor mengenai perizinan operasional Pusat Kajian Pengembangan Pesantren Nusantara. Secara resmi pusat pengkajian ini diresmikan pada tanggal 19 Oktober 2017 oleh Kementrian Agama, H. Lukman Hakim Saifuddin.Salah satu tujuan dari pendirian lembaga ini dalam rangka membangun sinergi antara institusi pondok pesantren dengan institusi perguruan tinggi yang harapannya institusi pendidikan mampu membentuk karakter kebangsaan di masa mendatang tidak lepas dari proses pembangunan manusia (pkppn wordspress).

Secara kelembagaan PKPPN adalah non organisasi tata kerja (ortaker). Secara struktural penasehat dari PKPPN di bawah arahan Wakil Rektor 1 UIN Raden Mas Said.Sedangkan secara tugas dan fungsi PKPPN sejalan dengan Lembaga Penelitian dan Pengabdian Kepada Masyarakat (LP2M). Namun secara khusus berada dalam aspek pesantren dan perguruan tinggi.Visi dari PKPPN adalah menjadi lembaga yang berepan dalam mengembangkan sinergi keimuan dan kebijakan publik yang berkaitan dengan pesantren dan perguruan tinggi. Nilai-nilai pesantren menjadi penting untuk diinternalisasikan dalam perguruan tinggi.

Kemudian pada Januari tahun 2021 PKPPN secara resmi berstransformasi menjadi PPM-PIN. Spirit perjuangan PKPPN kemudian dilanjutkan melalui PPM-PIN yang harapaannya bisa menjangkau masyarakat dan pendidikan lebih luas dan dalam. Berbagai kegiatan inspiratif dalam mengkampanyekan moderasi beragama. PPM-PIN mampu membaca situasi dan merespon kondisi masyarakat di era 4.0 baik secara pemikiran maupun gerakan, misalkan mengadakan pelatihan literasi media untuk para mahasiswa.

Gagasan mengenai literasi media baru muncul dipermukaan dengan membawa misi membuat para pengguna media untuk lebih kritis dalam mengkonsumsi, memproduksi dan menyebarkan pesan-pesan melalui media baru (Rianto, 2019). Menururt Potter 2009, ketrampilan literasi media dapat mencakup beberapa aspek diantaranya kemampuan mengakses, menganalisis, mengevaluasi dan mengkomunikasikan pesan dalam berbagai bentuk (Eristi, 2017). Berdasarkan data yang 
didapat dilapangan subjek kedua yaitu AW mengemukakan bahwa kemampuan literasi media menjadi sebuah kebutuhan dasar manusia.

"Kaitannya dengan paham, radikalis, kita harus memiliki kemampuan literasi media, agar kita bisa membedakan platform mana yang bermuatan radikalis, platform mana yang moderat. Misalnya dalam konteks jihad, mereka menyuarakan secara keras. Maka media konvensional juga turun langsung untuk mengcounter isu-isu radikal" (Wawancara,Subjek kedua. AW. Selasa 20 April 2021)

Untuk mewujudkan adanya literasi media, maka dapat dilakukan dengan beberapa cara antara lain, Pertama memberikan sumbangsih dengan cara membangun perpustakaan yang lengkap via internet sehingga bisa menjadikan rujukan pemikiran hitoris dan agamis dalam menyebarkan paham modernisasi dan menghadang paham radikalisme. Kedua, memberikan wadah masyarakat berupa grup diskusi via medsos guna menyebarkan paham wasathiyah secara masif. Ketiga, memberikan ruang da'i dan cendikiawan untuk melangsungkan ceramah secara fisik, yang dimaksudkan agar memuaskan kebutuhan intelektual melalui berbagi ilmu seminar dan workshop yang di sebarkan melalui media audio visual dan tulisan, sehingga konten ini dapat dijangkau oleh siapa saja dan masyarakat dapat memahami konsep wasathiyah secara utuh. Keempat, perlunya digelar dialog antara konsep Wasathiyah melalui berbagai sarana visual dan audio-visual yang berdakwah mengenai konsep Wasathiyah di kalangan publik. Kelima, mengajak masyarakat untuk turut aktif dalam mengkampanyekan agar masyarakat ikut program serta dalam edukasi konsep Wasathiyah. Keenam, perlunya mengembangkan program pendidikan dan pembelajaran sikap toleran dalam beragama dan menjauhi sikap ekstrem terutama di kalangan anak muda (Kosasih, 2019).

Menghadapi perkembangan teknologi dan informasi yang begitu pesat, PPMPIN turut bergerak mengcounter issue melalui media, yaitu dengan memberikan bimbingan kemampuan literasi media sebagai upaya moderasi beragama. Berikut berbagai kegiatannya:

\section{a. LISAN (Literasi Islam Santun dan Toleran)}

Program ini merupakan kerjasama dengan Wahid Foundation yang mana tujuan dari kegiatan ini adalahuntuk mengkampanyekan secara masif toleran dan nilai nilai islam santun melalui rujukan kitab-kitab Islam klasik. Sasaran dari program ini adalah generasi milenial yang mana begitu erat dengan media sosial. PPM-PIN mengedukasi generasi milenial yaitu siswa madrasah dan mahasiswa perguruan tinggi. Dikutip dari chanel youtube "Islam Santun", Khasan Ubaidillah selaku sekretaris PKPPN mengungkapkan bahwa 
"Peserta Lisan santun diharapkan dapat mengkampanyekan Islam yang santun dan tolerandi dunia nyata dan media sosial melalui berbagai varian, memes, video kreatif dan varian-varian kreatif lainnya untuk menyampaikan nilai positif dari pesantren untuk masyarakat secara lebih luas" (Islam Santun, 2021)

Kegiatan ini diawalai dengan literasi kitab kuning. Setelahnya, peserta diarahkan untuk berziarah ke makam mbah liem, yang mana beliu adalah tokoh ulama yang mencetuskan jargon "nkri harga mati" melalui kegiatan ziarah ini, peserta diharapkan dapat merefleksikan perjuangan beliau, yang kemudian diinternalisasikan dalam diri masing-masing. Kemudian dilanjutkan pada kegiatan inti yaitu Workshop Lisan Santun. Workshop ini dibagi menjadi 3 peminatan yaitu meliputi Literasi media masa, literasi media sosial dan literasi digital. Out pout dari pelatihan ini adalah adanya prodak yang dihasilkan dari peserta sebagai upaya mengkampanyekan Islam santun dan toleran. Melalui kegiatan Lisan Santun ini, PPM-PIN mencetak duta lisan.

"Nah itu lisan ini mencetak duta lisan, dimana para pemuda itu nantinya menyebarkan Islam yang ramah, yang santun yang nggak intoleran.Jadi dari lisan itu, kita mengkampanyekan terorisme, bom kaya gitu" (Wawancara.S1.AK. Minggu, April 2021).

Duta Lisan ini adalah sosok generasi milenial yang bertugas menyampaikan dan mengkampanyekan Islam yang ramah dan toleran, baik di kehidupan nyata maupun di dunia media sosial.

\section{b. Aktif Medsos}

Dalam rangka menyemarakkan media sosial yang moderat dan santun, PPMPIN turut aktif di berbagai platform media sosial, mulai dari IG,Facebook, Twitter, Youtube.. Secara garis besar media sosial yang teradapat di PPM-PIN bertujuan untuk mengkampanyekan secara masif mengenai literasi media sebagai upaya moderasi beragama. Melelui media sosial ini kiprah PPM-PIN menjadi lebih dikenal oleh masyarakat dan khususnya civitas akademik IAIN Suarkarta. Kara-kata mutiara yang di update di media sosial PPM-PIN memberikan motivasi tersendiri dalam menyampaikan isla yang santun. Lebih lanjut berdasarkan hasil wawancara di lapangan, PPM-PIN memiliki akun youtube official dengan nama akun "Islam Santun". Video yang dipload berisikan project yang dimiliki PPM-PIN, podcast diantaranya judul videonya yaitu : "Al-Qur'an satu tafsuirnya banyak", "Tips meraih kebahagiaan Imam Al-Qurthubi", "Merawat bangsa da budaya ala Samber Nyowo", "Memperkuat Indonesia dengan moderasi beragama". Podcast tersebut memiliki tujuan untuk memberikan pembelajaran dan miningkatkan keilmuan mengenai ajaran Islam yang santun dan ramah. 


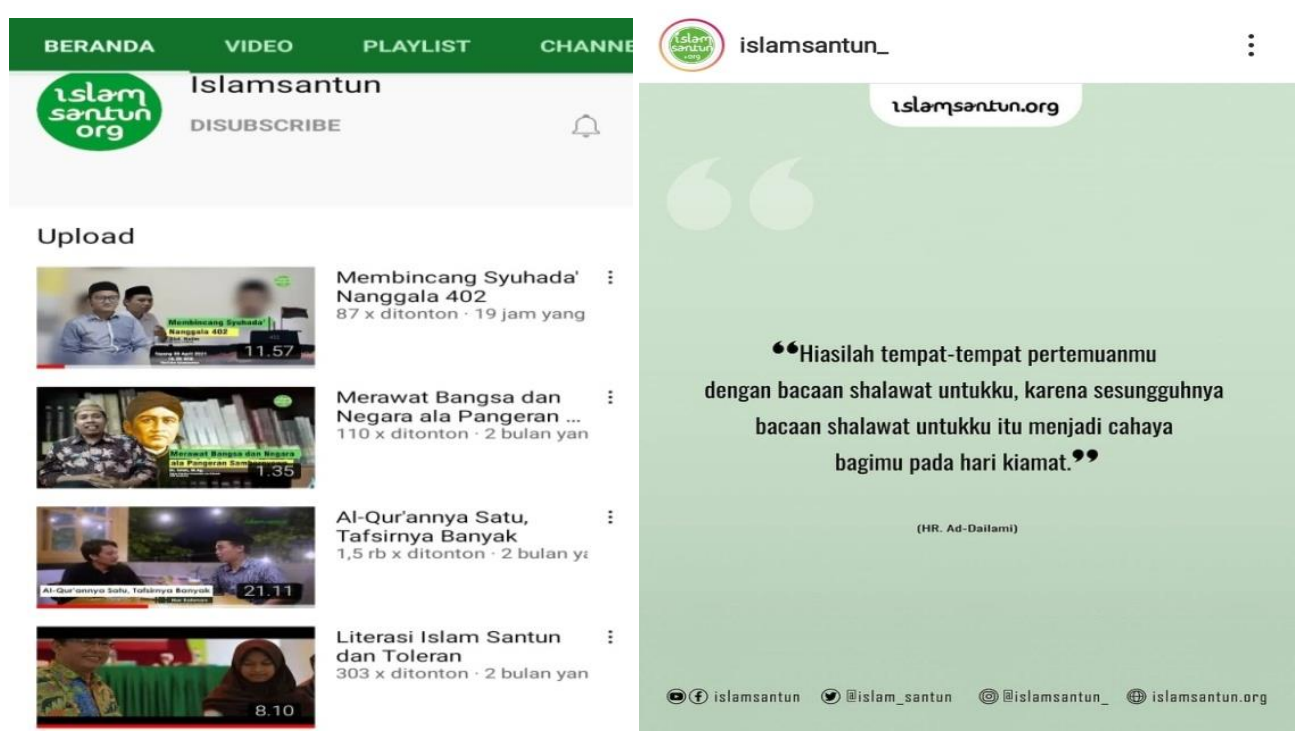

Gambar 1. Akun Youtube Islam Santun Gambar 2. Hadis insppiratif ig @islamsantun

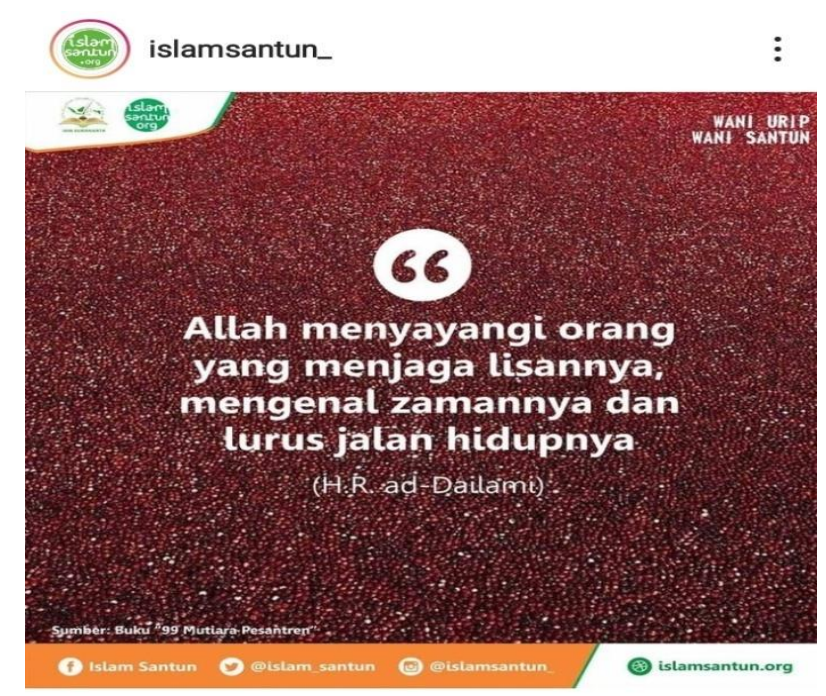

Gambar 3. Hadis inspiratif ig @islamsantun

\section{a. Islam Santun}

Islam santun adalah media resmi yang dikembangkan PPM-PIN sebagai tindak lanjut dari Literasi Islam Santun. Platform digital inimerupakan wadah rujukan ilmu pengetahuan keislaman yang mana fokus pada menyebarkan nilai-nilai moderasi dan Islam yang santun. Berdasarkan data yang ditemukan melalui wawancara, Islam santu terlah tergabung secara resmi menjadi bagian dari media muslim Indonesia.Islam santun 
bertugas merespons fenomena sosial masyarakat dari berbagai perspektif baik dari kalangan akademisi maupun praktisi. Terdapat ragam menu kajian dalam menyampaikan melalui tulisan, hal ini meliputi bilik pesantren, tokoh, ibadah, opini, peristiwa, kisah, resensi buku. Posisi PPM-PIN dan Islam santun senantiasa beriringan dalam melakukan kegitan mengkampanyekan moderasi beragama. Berbagai kegiatan Islam santun melibatkan mahasiswa. Hal ini dapat dilihat dari bimbingan yang dilakukan PPM-PIN kepada organisasi internal mahasiswa. Platform ini dapat dikunjungi melalui alamat https://islamsantun.org/ .

Berdasarkan data yang ditemukan di lapangan, Islam santun telah mencetak beberapa buku, antaralain : 99 Mutiara Pesantren, Ingin Sholeh, Merasa Sholeh Jangan, Beragama di Masa Corona. Dalam buku Beragama di Masa Corona, mengundang para akademisi dan mahasiswa untuk memberikan sumbangsing essay menyikapi fenomena pandemi corona. Salah satu darinya adalah tulisan Dosen UIN Raden Mas Said, hasil karya dari Abraham Zakky Zulhazmi yang berjudul "Melawan Corona Melawan Hoaxs". Tulisan ini merefleksikan fenomena masyarakat tentang maraknya fenomena hoaks dimasa pandemi. Maka dari itu hoaks bisa dilawan dengan memiliki kemampuan literasi digital. Literasi digital sangat penting karena di era digital ini, masyarakat perlu berfikir kritis dalam menerima dan menyebarkan informasi.

Tabel 2 Bimbingan Literasi Media dan Pengarusutamaan Moderasi Beragama PPMPIN

\begin{tabular}{l|l}
\hline Nama Kegiatan & Pendampingan dan Output \\
\hline Literasi Islam Santun (LISAN) & $\begin{array}{l}\text { Mencetak duta LISAN sebagai citra dari } \\
\text { anak milenial atau pelajar yang moderat }\end{array}$ \\
\hline Aktif Medsos & $\begin{array}{l}\text { Menyebarkan Islam yang ramah melalui } \\
\text { media sosial }\end{array}$ \\
\hline Islam santun & Mewartakan konten-konten moderat \\
\hline
\end{tabular}

Ketika narasi moderasi beragama diviralkan dengan bentuk kekinian yaitu alam bentuk meme ataupun konten tertentu dan pesan tertentu, maka hal ini akan mempu mengarahkan pola pikir masyarakat untuk berpikir moderat dalam setiap tindakan dan perilaku. Lebih dalam dari itu, narasi moderasi beragama yang diviralkan dalam bentuk konten itusejatinya bergerak untuk menuju pengarustamaan (mainstreaming) dalam 
menggiring sebuah wacana pikiran yang sebelumnya masih belum terbentuk dengan sempurna.Ini berarti bahwa meme sejatinya hidup secara kultural dengan mengembangkan potensi manusia melalui tingkah laku (perhatian, persepsi pikiran) yang bertujuan untuk menciptakan energy. Yusuf mengklaim bahwa meme telah mengkopi dirinya sendiri agar tumbuh dan hidup dalam pikiran manusia sebagai tempat hidupnya (Kosasih, 2019).

Jika dikaitkan dalam teks keagamaan yaitu Al-Qur'an penyampaian informasi yang berakhlak tercermin dalam ajaran Islam. Berikut ayat Al-Qur'an yang tercermin sebagai tuntunan umat manusia dalam menggunakan media sosial, antara lain: Pertama,Menyampaikan informasi dengan benar, juga tidak berbohong pada kondisi kenyataan yang terjadi (QS. Al-Hajj: 30). Kedua, bijaksana, memberikan nasihat yang abik, serta argumentasi yang jelas, terstruktur dan baik (qs. An-Nahl: 125). Hal ini dimaksudkan bahwa terdapat ragam karakteristik pertemanan di media sosial, maka dalam menyampaikan informasi hendaknya disampaikan dengan mudah dibaca dan dicerna dengan tata bahasa yang baik. Keempat, memvalidasi fakta. Dalam mencapai kecepatan data dan fakta sebagai bahan buku informasi yang akan disampaikan seorang muslim hendaknya mengkonfirmasi ulang agar tidak terjadi kadzib, ghibah, fitnah dan namimah (QS. Al-Hujarat : 6). Ini merarti bahwa kecerobohan dalam menyebutkan dan memberi informasi kepada pihak tertentu yang tersebar diranah publik, memiliki potensi pencemaran nama baik sebagaimana larangan dalam UU ITE. Kelima, tidak mengolokolok, mencaci maki, atau tindakan penghinaan sehingga menyebabkan kebencian (QS. Al-Hujarat:110). Karakteristik dunia maya yang begitu cair dan bebas, memungkinkan melakukan perilaku negative kepada pihak lain sehingga memunculkan provokasi dan adu domba (framing dan trolling). Kelima, menghindari prasangka buruk atau suudzan (QS. Al Hujurat: 12) (Kosasih, 2019)

Moderasi beragama menjadi penting dikaji, dan digaungkan sebagai framing mengelola kehidupan masyarakat yang multikulturdan menguatkan moerasi beragama.Fenomana tersebut tak luput menjadi sorotan Kementrian Agama. Kementrian agama melihat perlunya perlunya cara beragama yang inklusif dan toleran unutuk bisa merebut panggung digital (Novia \& Wasehudin, 2020). Berdasarkan teori 
diatas, relevan dengan apa yang selama ini dilakukan oleh PPM-PIN bahwa Islam santun teragabung dalam lingkaran media Islam. Dimana sindikat ini merupakan gabungan dari media Islam yang moderat, seperti nu noline, alif.id, dan lain sebagainya. Islam santun bertugas turut merespond isu yang sedang berkembang di kalangan masyarakat dan berkontribusi menggaungkan moderasi agama dan Islam yang rahmatan lil'alamin.

Menurut subjek kedua dalam penelitian ini, bahwa moderasi beragama ini adalah way of life, dimana nilai-nilai dari moderasi beragama ini mampu diterakan dalam kehidupan sehari-hari. Melalui mderasi beragama ini terciptalah kehidupan yang damai antara umat manusia.

"Moderasi beragama itu bukan tujuan, tapi universalitas antar manusia itu, yaa kerukunan, kedamaian itu. Cara berpikir moderasi beragama tidak hanya sebagai slogan tapi mewujudkan dalam tindakan. Tujuannya adalah kedamaian umat manusia" (Wawancara.S2.NR, Selasa 20 April 2021).

Sedangkan menurut subjek keempat, bahwasa moderasi beragama adalah cara berpikir. Terdapat beberapa elemen prinsip moderasi beragama yang harus diinternalisasikan dalam setiap individu. "tawasud yang berarti tidak terlalu ekstrem, tidak terlalu liberal, moderat ditengah-tengah. Tawazun bersifat adil, tasamuh toleran terhadap perbedaan... itu adalah bagiandari moderat. Jadi itu lebih kepada manhajul fiqr. (Wawancara. S4. AH, Selasa 20 April 2021)

Perjuangan PPM-PIN dalam menggaungkan moderasi beragama di lakukan secara masif pada ranah dunia pendidikan, khususnya pendidikan berbasis Islam Nusantara yaitu RA, MI, MTs, MA dan Pondok Pesantren. Hal ini dapat dilihat dari kontribusi PPM-PIN IAIN Surakarta dalam membuat buku panduan Moderasi Beragama untuk para siswa RA, MI, Mts dan MA. Buku ini telah didesminasikan oleh KSKK Madrasah Ditjend Pendidikan Islam Kementrian Republik Indonesia. Maka buku ini bisa diakses oleh Madrasah-madrasah dalam rangka menanamkan karakter moderasi beragama pada peserta didik. Buku ini memberikan gambaran atau praktik keseharian dengan memegang teguh nilai-nilai moderasi beragama. Misal, saling menghormati perbedaan, silaturahmi, mencintai negeri, saling tolong menolong dan sebagainya. 

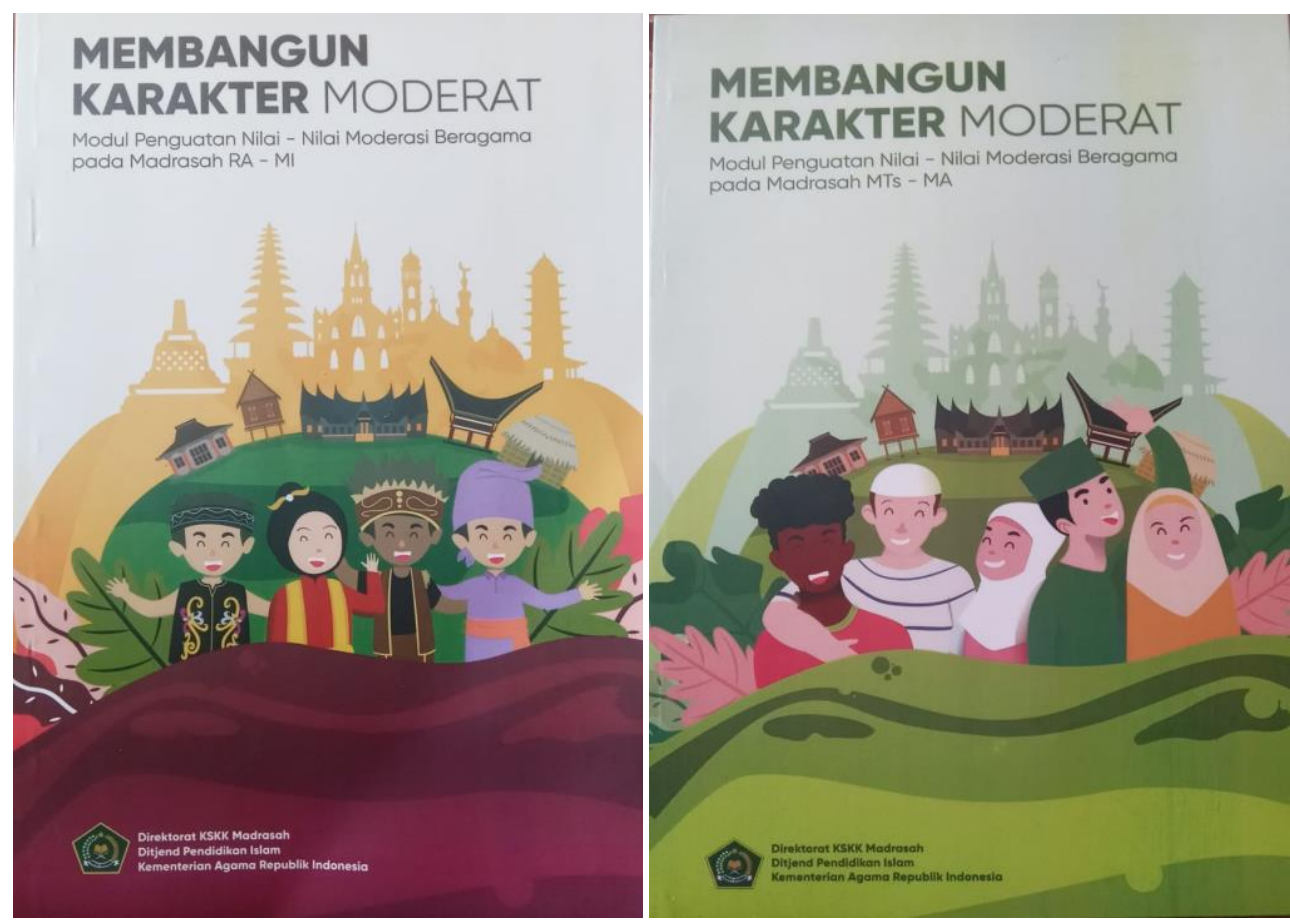

Gambar 4. Buku Panduan Moderasi Beragama

Untuk mencapai tujuan PPM-PIN dalam menggaungkan moderasi beragama, maka hal ini tidak lepas dari kerjasama dengan lembaga, komunitas atau organisasi yang sejalan dengan visi misi nya. Berbagai organisasi dan lembaga baik dari organisasi mahasiswa, lembaga tingkat regoional, nasional hingga internasional yang telah bekerjasama dalam menjalankan setiap kegiatan.

Tabel 3. Kerjasama PPM-PIN

\begin{tabular}{l|l|l}
\hline $\begin{array}{l}\text { Nama Organisasi } \\
\text { Lembaga }\end{array}$ & Kegiatan & $\begin{array}{l}\text { Keterangan atau Rencana } \\
\text { Tindak Lanjut (RTL) }\end{array}$ \\
\hline Wahid Foundation & Lisan Santun & Mencetak duta lisan \\
\hline $\begin{array}{l}\text { Direktorat KSKK } \\
\text { Kemenag RI }\end{array}$ & $\begin{array}{l}\text { Merancang Buku Panduan } \\
\text { Moderasi Beragama untuk } \\
\text { siswa RA, MI, Mts dan } \\
\text { MA }\end{array}$ & $\begin{array}{l}\text { Disminasi buku panduan } \\
\text { Moderasi Beragama untuk } \\
\text { siswa RA, MI, MTs dan MA } \\
\text { se-Indonesia }\end{array}$ \\
\hline $\begin{array}{l}\text { Organisasi } \\
\text { Kampus }\end{array}$ & $\begin{array}{l}\text { Menjembatani mahasiswa } \\
\text { dalam melakukan kegiatan } \\
\text { yang beraitan dengan } \\
\text { moderasi beragama }\end{array}$ & $\begin{array}{l}\text { Memberikan jaringan atau } \\
\text { merekomendasikan pemateri } \\
\text { kegiatan }\end{array}$ \\
\hline DEMA IAIN Surakarta & Pendampingan PBAK sejak & Bersinergi \\
\hline
\end{tabular}




\begin{tabular}{l|l|l}
\hline & tahun 2017-sekarang & $\begin{array}{l}\text { mahasiswa dalam } \\
\text { merancang tema besar } \\
\text { PBAK serta }\end{array}$ \\
\hline BNPT & Bedah buku & $\begin{array}{l}\text { Memberikan } \\
\text { mimbar akademik }\end{array}$ \\
\hline Kedutaan Amarika & $\begin{array}{l}\text { Dalam rangka mecari } \\
\text { aktivisme Islam }\end{array}$ & $\begin{array}{l}\text { Mengirimkan personel } \\
\text { PPM-PIN untuk presentasi } \\
\text { ke Amerika mengenai } \\
\text { kiprah PPM-PIN }\end{array}$ \\
\hline Pesantren Elqudsia Kudus & $\begin{array}{l}\text { Memberikan pelatihan } \\
\text { Jurnalistik kepada santri } \\
\text { elkudsia }\end{array}$ & $\begin{array}{l}\text { Membekali pengalaman } \\
\text { santri dalam kepenulisan }\end{array}$ \\
\hline
\end{tabular}

\section{Simpulan}

Derasnya informasi membuat masyarakat harus berhati-hati dan memiliki tindakan preventif sisi buruk media sosial yaitu dengan memilikinya kemampuan literasi media.PPM-PIN adalah pusat pengkajian yang fokus mengkampanyekan literasi media sebagai upaya moderasi beragama sekaligus membimbing masyarakat dan generasi milenial (siswa madrasah dan mahasiswa perguruan tinggi) untuk menyebarkan Islam yang ramah, satun dan toleran. Untuk mencapai cita-cita PPMI-PIN tersebut, terdapat beberapa kegiatan diantaranya yaitupertama, mengadakan workshop lisan santun, dimana kegiatan ini menghasilkan duta lisan santun, kedua yaitu aktif mengkampanyekan melalui sosial media, ketiga yaitu aktif kepenulisan di platfom islamantun.org.Maka berdasarkan hasil yang ditemukan oleh peneliti, bahwa bimbingan literasi media yang dilakukan oleh PPM-PIN IAIN Surakartamampu menumbuhkan sikap kesadaran toleransi dan keharmonisan dalam kehidupan bermasyarakat. Selain itu PPM-PIN juga menghasilkan duta lisan yang berasal dari kalangan muda yang bertugas turut serta mengkampanyekan nilai-nilai Islam yang ramah.

\section{DAFTAR PUSTAKA}

Abdullah, A. H., \& Nento, S. (2021). Contructing Religious Moderation in Islamic Higher Education. Al-Ulum, 2l(1), 166-186. https://doi.org/10.30603/au.v21i1.2084

Aisyiyah, Putri. (2021). Literasi Media Sketsa Khalayak di Hadapan Media. Intrans Publishing. 
Rahmaditta Kurniawati dan Maemonah

Awwaliyah, N. M. (2019). Pondok Pesantren Sebagai Wadah Moderasi Islam Di Era Generasi Millenial. Islamic Review : Jurnal Riset Dan Kajian Keislaman, 8(1), 3662. https://doi.org/10.35878/islamicreview.v8i1.161

Bagi, B., Milenial, G., \& An, Q. U. R. (2021). KONSEP INTERNALISASI NILAI-NILAI MODERASI THE CONCEPT OF INTERNALIZING THE VALUES OF RELIGIOUS. 4(1), 72-82.

Briandana, R., \& Ninditya. (2019). Media Literacy: An Analysis of Social Media Usage among Millennials. International Journal of English Literature and Social Sciences, 4(2), 488-496. https://dx.doi.org/10.22161/ijels.4.2.44

Eristi, B., \& Erdem, C. (2017). Development of a Media Literacy Skills Scale. $\begin{array}{lll}\text { Contemporary Educational Technology, } & \text { 8(3). }\end{array}$ https://doi.org/10.30935/cedtech/6199

Fuadi, Moh. A., Kholis, M. N., Zulhazmi, A. Z., \& Ibrahim, R. (2021). Strenghtening Religious Moderation to Counter Radicalsm at IAIN Surakarta. Al-Tahrir, 21(2).

Hefni, W. (2020). Moderasi Beragama dalam Ruang Digital: Studi Pengarusutamaan Moderasi Beragama di Perguruan Tinggi Keagamaan Islam Negeri. Jurnal Bimas Islam, 13(1), 1-22. https://doi.org/10.37302/jbi.v13i1.182

Husain, O. S. (2020). NILAI-NILAI MODERASI ISLAM DI PESANTREN ( Studi Kasus pada Ma ' had Aly As 'adiyah Sengkang Kabupaten Wajo Sulawesi Selatan ).

Ibrahim. (2020). Manajemen Pendidikan Moderasi Beragama di Era Digital. Journal of International Conference On Religion, Humanity and Development, 83-96.

Islam Santun. (2021, February). Literasi Islam Santundan Toleran.

Kaplan, O. U. (2019). Media Literacy in a Changing Process in Turkey. Electronics, Computers and Artificial Intelligence Intternational Cnference, Romania.

Kementrian Agama RI. (2020). Moderasi Beragama. Badan Litbang dan Diklat Kementrian RI.

Kosasih, E. (2019). Literasi Media Sosial dalam Pemasyarakatan Sikap Moderasi Beragama Social Media Literacy on Socializing Religous Moderate Action. Bimas Islam Vol 12 No. 1 ISSN2657-188 (Online) ISSN 1978-9009 (Print), 12(1).

Mahrus, E., Prasojo, Z. H., \& Busro. (2020). Massages of Religious Moderation Education in Sambas Islamic Manuscripts. Journal Madania, 24(1), 39-48.

Mansyur, F. M., \& Husni, H. (2020). Promoting Religious Moderation through Literary-based Learning: A Quasi-Experimental Study. International Journal of Advanced Science and Technology, 29(6), 5849-5855.

Musa, R., Ibrahim, N. A., \& Adam, A. A. (2017). The Factors and Outcomes of Social Media Dependency Framework. Pertanika Jouranls, 25(S), 333-340.

Novia, W., \& Wasehudin, W. (2020). Penggunaan Media Sosial dalam Membangun Moderasi Beragama di Masa Pandemi Covid-19 di Kota Tangerang. Hanifiya: 
Jurnal Studi Agama-Agama, 3(2), 99-106. https://doi.org/10.15575/hanifiya.v3i2.10017

O'Hara, K., \& Stevans, D. (2009). The Devil Long Tail Religious Moderation and Extrimism on Web. IEEE Computer Society, 24(06).

Rianto, P. (2019). Literasi Digital Dan Etika Media Sosial Di Era Post-Truth. Interaksi: Jurnal Ilmu Komunikasi, 8(2), 24. https://doi.org/10.14710/interaksi.8.2.24-35

Sabrina, A. R. (2019). Literasi Digital Sebagai Upaya Preventif Menanggulangi Hoax. Communicare: Journal of Communication Studies, 5(2), 31. https://doi.org/10.37535/101005220183

Sutrisno, E. (2019). Aktualisasi Moderasi Beragama di Lembaga Pendidikan. Jurnal Bimas Islam, 12(2), 323-348. https://doi.org/10.37302/jbi.v12i2.113

Sutrisno, E. (2020). Moderasi Dakwah di Era Digital dalam Upaya Membangun Peradaban Baru. Al-INSAN Jurnal Bimbingan Konseling Dan Dakwah Islam, 1(1), 56-83.

Syam, H., \& Nurrahmi, F. (2020). "I Don't Know If It Is Fake or Real News" How Little Indonesian University Students Understand Social Media Literacy. Jurnal Komunikasi: Malaysian Journal of Communication, 36(2), 92-105. https://doi.org/10.17576/JKMJC-2020-3602-06

Tutiasri, R. P., \& Kusuma, A. (2019). Millennial generation and family literacy within the dissemination of hoax in Whatsapp group. Jurnal Informasi, 50(2), 153-164. https://doi.org/10.21831/informasi.v50i2.28463

Ulya, U. (2018). Post-Truth, Hoax, dan Religiusitas di Media Sosial. In Fikrah (Vol. 6, Issue 2, p. 283). https://doi.org/10.21043/fikrah.v6i2.4070 
